Saeculum Christianum

vol. XXII (2015)

pp. $23-35$

\author{
ANNA GLUSIUK* \\ WNHiS UKSW, Warszawa
}

\title{
TREATMENTS TO REFINE ONE'S BODILY BEAUTY ACCORDING TO THE TEACHINGS OF TROTA OF SALERNO
}

The aim of this article is to present the ways in which women living in Italy in the 11th century took care of their bodies. Based on the works titled De ornatu mulierum and De curis mulierum authored by Trota, the most widely-known medical practitioner associated with the Schola Medica Salernitana, the author wishes to present some of the treatments used by women in Southern Italy to emphasise their beauty. Furthermore, given the modern stereotypes pertaining to hygiene and bodily treatments of the Middle Ages, this study also seeks to answer the question: "did the women of those times really take such great care of themselves"?

Women always sought, and still do, to stop the flow of time and maintain their attractiveness for as long as possible. Notwithstanding the fact that Medieval beauty standards differed from those of the Renaissance or Modern eras, women always viewed taking care of one's body as a matter of great importance. Even centuries back, they sought to attain the best results possible using creams and ointments obtained using the recipes available at the time. Owing to Trota's treatises, one may learn what kinds of treatments were used by the women of the 11th century in order to help, for example, keep their skin soft, smooth and clear, their hair shiny, and their teeth white.

Before discussing Trota and her remedies, however, it has been deemed necessary to first briefly present the Schola Medica Salernitana, one of the era's most important centres of medical sciences in Western Europe. In fact, as described further in the text, people did not merely visit the Schola to undergo medical treatment; many, in fact, would go there to learn the medical sciences from famous physicians such as Alfanus or Garioponto. The most famous woman associated with the Medical School of Salerno, Trota, will be discussed as well; her name was known not just in Salerno or Italy, but abroad as well. Secondly, the author will seek to familiarise the reader with the figure of this esteemed physician, whose renown among her peers went beyond merely quoting her in their own treatises; they would seek her advice pertaining to medicine as well. Given the role of women in Medieval society, this seems almost extraordinary. Their role in society was fixed: they would be expected to marry, bear offspring (preferably male), and take care of the affairs of their husbands,

* Translated by Skrivanek Sp. z o.o. 
homes and children. It was a rare occurrence for women to learn how to read and write, as, according to the approach of the time, this kind of education was not necessary for them ${ }^{1}$. Quite on the contrary, starting at a young age, they would be taught what was believed to be useful when performing their roles as housewives and mothers. Certainly, one should not generalise, seeing as well-educated women are not unknown to history - such as, for example, Dhuoda, Héloïse, Christine of Pisan, Hildegard of Bingen, and Hroswitha, to name a few. Thirdly and finally, this study shall present some of Trota's treatments described in De ornatu mulierum and De curis mulierum, and employed by the women of the time to care for their bodies.

\section{The Medical School of Salerno}

One may distinguish three periods in the history of the Schola Medica Salernitana: its poorly-documented beginnings, the school's heyday that lasted between the 11th and 13th centuries, and, finally, a period of stagnation and decline.

Given the scarcity of documentation, the beginnings of the school are rather uncertain. There exist no known and trustworthy accounts that could shed light on its creation. Antonio $\mathrm{Mazza}^{2}$, probably the first to occupy himself with the School's history, authored a legend based on the apocryphal Chronica Elini ${ }^{3}$. According to the work, four masters arrived in Salerno, each of them teaching in a different language: Rabinus Elinus Hebraeus primus Salerni medicinam Hebraeis de litera hebraica legit. Pontus Graecus de litera graeca Graecis. Adala Saracenus Saracenis de litera Saracenica. Magister Salernus medicinam de litera latina legit ${ }^{4}$.

Regardless of the circumstances, the legend is not to be believed. The first mentions of the practise of medicine in Salerno - if not yet in the form of a structured and organised

\footnotetext{
1 The opinions on female education among the men of the time were not uniform. Francis from Barberino, for example, maintained that girls from noble families should be literate in order to, for example, take care of their properties in the future; on the other hand, the very same man doubted whether daughters of commoners should receive education and stated that the daughters of merchants and artisans should be barred from it. Cfr. E. Power, Donne nel medioevo, M.M. Postan (cur.), Jaca Book, Milano 19994, p. 74; Idem, L'educazione delle donne, in: Né Eva né Maria. Condizione femminile e immagine della donna nel Medioevo, M. Pereira (ed.), Zanichelli, Bologna 1981, p. 103; Furthermore, in Lessons for my Daughter, Anne of France recommended reading books to her daughter Susan. Among the authors she mentioned were, for example, Saint Louis and Saint Peter of Luxembourg. Cfr. Anne of France, Insegnamenti alla figlia Susanna, in: C. Xodo Cegolon, Lo specchio di Margherita, C.L.E.U.P., Padua 1988, p. 89. The Parisian Household Book and Chrisine of Pisan both recommended teaching all women; this opinion was echoed in The Book of the Knight of the Tower, which recommended teaching women literacy, stating that women should be able to read the Scriptures; cfr. G. Tour De La Landry, The Book of the Knight of La Tour-Landry: Compiled for the Instruction of His Daughters, London 1868, p. 117. Other writers, however, such as, for example, Philip of Navarre, stated that all females should be barred from education; cfr. E. Power, Donne nel medioevo, Milano 1999, p. 74.

2 It would appear that he was the first to occupy himself with the history of the Medical School of Salerno. In 1681, Antonio Mazza published his work, Historiarum Epitome de rebus Salernitanis, in Naples. Regimen Sanitatis Salernitani sive Scholae Salernitanae de Conservanda bona vatetudine praecepta, penned by Johan C.G. Ackermann, followed in 1790. The third historian to be remembered in this context is Salvatore de Renzi, publishing his Collectio Salernitana between 1852 and 1859. The work was followed in 1900 by Magistri Salernitani nondum editi by P. Giacosa.

3 P.O. Kristeller, La Scuola di Salerno: il suo principio e il suo contributo alla storia della scienza, Salerno 1955 , p. 10
}

4 A. Mazza, Historiarum Epitome de rebus Salernitanis, Bologna 1681, p. 129. 
entity - were made by an anonymous author in the 10th century in Historia inventionis ac translationis et miracula Sanctae Trophimenae ${ }^{5}$. Describing the devotion to a certain saint, the author recounts a story that took place when the prefect of Salerno was Pulcari, i.e. between 867 and 878 . In the tale, a young spouse, named Teodonanda, fell gravely ill and her family decided to bring her to Salerno, where the famous archiater Gerolamo worked. Having visited the patient and consulted, as put by the author, librorum immensa volumina ${ }^{6}$, he is said to have stated that he was unable to save her. The account does not mention the school, but rather merely states that the famous Gerolamo worked there as a physician and had access to numerous books.

It should be added that, at the time, medicine was probably practised in Salerno much like in other Italian cities. Owing to its geographical location and climate, however, the city had certain advantages over the other locations. Furthermore, its fame as a centre of medicine grew in the Crusader era, when the wounded would seek treatment there before returning home or to the Holy Land. The fact that Salerno became famous for its medical practises was noted by Alfanus I, who was not just the archbishop of Salerno between 1057 and 10857, but also a physician and a poet. He would, in fact, say:

Tum medicinali tantum florebat in arte,

Posset ut hic nullus languor habere locum ${ }^{8}$.

There exists another account by the historian Richer of Reims ${ }^{9}$, who worked near the end of the 10th century, recounting a story of two physicians which took place at the French court, Derold and an anonymous doctor from Salerno. The former was preferred by the king, and the latter by the queen. The two were discussing medicine, with Derold gaining the upper hand in the debate. Unable to win, the Salernitan unsuccessfully attempted to poison his rival. Three days later, the physician from Salerno was poisoned by Derold as well, but survived thanks to his rival's mercy and the antidote he was given ${ }^{10}$. Richter does not mention either the School or the doctor's name, only using the word Salernitanus.

Another hint at the presence of famous physicians in Salerno comes from an anonymous chronicler of the Verdun bishops who wrote that, after his election in 985, bishop Adalbert II

Cfr. Historia inventionis ac translationis et miracula Sanctae Trophimenae in: Acta Sanctorum, Iul. II. 1721, 233-240.

6 Ibidem p. 240.

7 A. Mazza, Historiarum Epitome de rebus Salernitanis, Bologna 1681, p. 82.

8 S. De Renzi, Storia documentata della Scuola Medica di Salerno, Naples 1857, p. 190.

9 Richer of Reims was a tenth-century chronicler. He entered the Abbey of Saint-Rémi in Reims. It is unknown when he became a Benedictine monk. He studied history, literature, science and philosophy. He gained fame thanks to his Historianum libri IV, inspired by the famous Gerbert (the future Pope Sylvester II) cfr. G. Bruni, Richer di Reims in: Enciclopedia Italiana di scienze, lettere ed arti t. XXIX, Rome 1936, p. 263.

10 Richeri, Historiae II cap. 59 in: Monumenta Germaniae Historica, SS., III, 1839, p. 600-601. 
left for Salerno, but died shortly afterwards in $988^{11}$. It is worth noting that this information is also found in the work of another chronicler, Hugh of Flavigny ${ }^{12}$.

These accounts allow us to say that Salerno was already famous as a centre of medicine as early as in the 10th century. In fact, according to Kristeller, "one may consider the second half of the tenth century to be the beginning of the School of Salerno. This period seems to be far back in time enough to corroborate the traditional opinion that Salerno hosted the first European university"'13.

Approximately two centuries later - that is, in the 12th century - another Medieval writer, Orderic Vitalis ${ }^{14}$, stated in his Storia Ecclesiastica that Salerno was a city "quorum fama per orbem admodum divulgatur excellentia medicinalis peritiae"15. In the same century, a Spanish-born Jewish traveller, Benjamin of Tudela ${ }^{16}$, journeyed through the regions, visiting the Jewish communities. Starting his voyage in Navarra, he travelled through France and Italy, arriving in Naples. Writing of his travel to Salerno, he wrote that "journeying by sea", he reached "the city of Salerno, where the Christians have a school of medicine"17. The fact that Salerno was famous for medicine was confirmed by Romuald Guarna ${ }^{18}$ in his Chronicon: ...Salernum, civitatem medicine utique artis diu famosam atque precipuam ${ }^{19}$.

As noted hereinabove, the twelfth and thirteen centuries were the time that the School of Salerno flourished. This was when the best-known physicians, such as Gariopontus or

\footnotetext{
11 Gesta Episcoporum Virdunensium cap. 6 in: Monumenta Germaniae Historica SS, IV, Hannover 1841, p. 47: Hic vero honestus fuit atque humillimus, sed valde infirmus, tantamque corporis sui passus est inbecillitatem, ut ipso eodem anno benedictionis suae Salerniam causa salutis exposceret, nostris secum comitatis. Qui cum ibi moraretur, et a medicis curari non posset, reversus est Italiam, ibique ingruente morte, vocatis omnibus suis, tradidit abbatiam sancti Germani cuidam Rodulfo nepoti suo, qui vixit usque ad tempora domini Richardi episcopi plenus dierum; aliaque multa suis distribuentes, mortuus est.

12 Chronicon Hugonis in: Monumenta Germaniae Historica, SS. VIII 1848, p. 367: Is Salernum eodem anno benedictionis suae curationis grata profectus, reversus in Italia obiit 14 Kal. Mai, et relatum corpus eius Virduni sepultum est.

13 P.O. Kristeller, La Scuola di Salerno, op. cit., p. 13.

14 Orderic Vitalis, born in 1057 in Shrewsbury. He was a monk at the Saint-Evroult Abbey in Normandy. Between 1120 and 1140, he penned a work titled Historia ecclesiastica, starting with the beginnings of the Church and ending with his own era.

15 The ecclesiastical history of Orderic Vitalis, vol. IV, ed. M. Chibnall, Oxford 1973, p. 28.

${ }^{16}$ Apart from the fact that between the sixth and seventh decade of the 12th century, he visited Jewish communities in Europe and Asia, nothing is known of his life. After a long journey, he returned home with his notes, with an anonymous editor later combining them into the story. Cfr. Benjamin da Tudela, Libro di viaggi, L. Minervini (cur.), Palermo 1998, p. 11.

17 Benjamin da Tudela, Libro di viaggi, op. cit., p. 46.

18 Romualdo Guarna, Archbishop of Salerno from 1153 to 1181, physician and compiler of a universal chronicle. Writing of himself in Chronicon, he stated: In arte medicinae valde peritus. Further reading: G. Crisci, A. Campagna, Salerno Sacra, ricerche storiche, Salerno 1962, pp. 76-78; G. Crisci, Il cammino della Chiesa Salernitana nell'opera dei suoi vescovi (sec. V-XX), I, Naples-Rome 1976, pp. 239-260.

19 Romualdi Salernitani Chronicon, C.A. Garufi (ed.), Città di Castello 1935, p. 189.
} 
Gaurimpotus $^{20}$, Alfano $^{21}$, Costantino Africano ${ }^{22}$, Romualdo Guarna, and Giovanni Afflacio ${ }^{23}$, to name a few, worked there ${ }^{24}$.

In the 14th century, the School began shutting itself off from other cultures, causing the distance between it and the other universities of Italy and Europe to grow ${ }^{25}$. In the 16th and 17 th centuries, the School would only accept inhabitants of Salerno ${ }^{26}$, and, in January 1812, it was finally shut down based on the decree of 29 November 1811, issued by the King of Naples, Joachim of Murat ${ }^{27}$.

It is impossible to describe the history of the Schola Medica Salernitana without, at the very least, briefly addressing the presence of women, not merely as patients who sought treatment - above all, they were physicians and authors of texts pertaining to medicine ${ }^{28}$. At this point, it should be noted that scholars have not reached a consensus on the women's role in the School. On the one hand, for example, Salvatore de Renzi, an Italian historian of medicine, stated that in Salerno, women were treated by women ${ }^{29}$. This opinion is shared by Boggi, who states that the presence of women in the School as teachers and students alike was only natural ${ }^{30}$. On the other hand, however, Capparoni maintains that the women

\footnotetext{
20 According to De Renzi, Gariopontus practised medicine with the School from 1020 to 1050 . He was likely a contemporary of Pier Damiani, with the latter praising him in his works: Dicam quod mihi Garimpotus senex vir videlicet honestissimus, et apprime litteris eruditus; medicus, retulit. Gariopontus authored a treatise on fevers, but, most importantly, he wrote the Passionarius. Scholars, however, doubt whether he was truly the author of the latter work, given that Passionarius is often said to be a work of Galen. As emphasised by Kristeller, however, there is no doubt that the treatise was written by Gariopontus. Cfr. P.O. Kristeller, La Scuola di Salerno: il suo principio e il suo contributo alla storia della scienza, Salerno 1955, p. 15. Further reading pertaining to Gariopontus: S. De Renzi, Storia documentata, op. cit., pp. 168-181; S. De Renzi, Collectio Salernitana, I, op. cit., pp. 137-149; G. Vitolo, La Scuola Medica Salernitana come metafora della storia del Mezzogiorno in: La Scuola Medica Salernitana. Gli autori e i testi, D. Jacquart, A. Paravicini Bagliani (curr.), Florence 2007, p. 539.

21 Alfanus was one of the most famous people active within the School's structures in the 11th century. He was a monk at Montecassino, becoming the Archbishop of Salerno in 1058. In 1059, he was part of the Council of Rome and, in the same year, of the council of Benevento. It is known that, in 1063, he accompanied Gisulf II to Jerusalem. The following works are attributed to Alfanus: Premnon physicon seu stipes naturalium, De pulsibus, De quatuor humoribus cfr. S. De Renzi, Storia documentata, op. cit., pp. 188-194; S. De Renzi, Collectio Salernitana, op. cit., I pp. 132-136; G. Crisci, Il cammino della Chiesa Salernitana, op. cit., pp. 187-212; G. Crisci, A. Campagna, Salerno sacra, op. cit., pp. 70-73; G. Vitolo, La Scuola Medica Salernitana, op. cit., p. 540.

22 Costantine, of Arab origins, arrived in Salerno around 1077, remaining there for some time, later moving to Montecassino, where he occupied himself mainly with translating works pertaining to medicine from Arabic; cfr. S. De Renzi, Storia documentata, op. cit., pp. 218-227; S. De Renzi, Collectio Salernitana, op. cit., I, pp.165-172; G. Vitolo, La Scuola Salernitana, op. cit., p. 540.

23 Cfr. S. De Renzi, Storia documentata, op. cit., pp. 229-235; S. De Renzi, Collectio Salernitana, op. cit., I, pp. 174-180.

24 Further reading: S. De Renzi, Storia documentata della Scuola Medica di Salerno, 2a, Naples 1857; P.O. Kristeller, La Scuola di Salerno: il suo principio e il suo contributo alla storia della scienza, Salerno 1955.

25 Cfr. A.M. Garbarino, Donne e medicina nel medioevo. La Scuola Medica Salernitana, Empoli 2005, pp. 32-33.

26 Cfr. Ibidem, p. 33.

27 Cfr. S. De Renzi, Collectio Salernitana, op. cit., I, pp. 415-416.

28 A study pertaining to the women associated with the Medical School of Salerno is under way.

29 Collectio Salernitana, op. cit., I, p. 153.

30 Trotula de Ruggiero. Sulle malattie delle donne, P. Cavallo Boggi (ed.), Turin 1979, p. 10.
} 
played the roles of nurses and midwives, but not physicians ${ }^{31}$. He adds, however, that when it came to gynaecologic and obstetric care, women could provide treatment to other women ${ }^{32}$.

In many cases, the names of the women associated with the Schola Medica remain unknown. However, the authors of medical treatises that worked in Salerno in the Middle Ages often mention so-called mulieres salernitanae that practised medicine ${ }^{33}$. These women, indeed, possessed knowledge of treatments of various diseases, as evidenced by the works of physicians associated with the College of Salerno ${ }^{34}$. For example, in Circa instans by Platearius, whom de Renzi believed to be possibly related to Trota's family ${ }^{35}$, the author often brings up the remedies of the said mulieres. Trota herself mentioned them in her own works as well ${ }^{36}$.

From the documents that survived until our times, it is known that the period between the 13th and 15th centuries witnessed the activity of women such as Abella of Salerno, who authored De atrabile and De natura seminis humani ${ }^{37}$, Berdefolia medica ${ }^{38}$, Rebeca Guarna, the author of De febribus, De urinis, and De embrione ${ }^{39}$. Constantia Mammana ${ }^{40}$, Mercuriade, who penned De crisibus, De febris pestilenti, De curatione vulnerum, and De unguentis $^{41}$, and Constance Calenda ${ }^{42}$.

\section{Trota and her works}

Little is known about one of the most important women in the history of the Medical School of Salerno. As emphasised by Cavallo Boggi in his "Trotula de Ruggiero. Sulle malattie delle donne", she was known by the names Trotula, Trotta, Trocta, Uxor Platearii, Mulier Sapiens, and Magistra. Authors who described her would also refer to her as Tortola, Trocula, Tuenda, Trotta, Trotula, Trocta, trott', tt', Truta, Trutella, Trorula, Tortula, Eros Juliae, Erotian, one of the women of Salerno, Dame Trot ${ }^{43}$. Having shown the multitude of variants of the name "Trota", it should be added that, in the period between the 11th and 13th centuries, the name "Trocta" was a fairly common one in Southern Italy ${ }^{44}$.

The date of her birth is unknown, but, according to documents gathered by de Renzi, Trotula was an active practitioner in Salerno as of 1050, and enjoyed great esteem even back

\footnotetext{
31 Cfr. P. Capparoni, Magistri salernitani nondum cogniti. Contributo alla storia e alla diplomatica della Scuola Medica di Salerno, Terni 1924, p. 14.

32 Cfr. Ibidem, p. 14.

33 Cfr. Trotula. Un compendio medievale, op. cit., p. 84.

34 Cfr. A.M. Garbarino, Donne e medicina nel medioevo, op. cit., p. 36.

35 S. De Renzi, Storia documentata, op. cit., p. 205.

36 Cfr. Trotula. Un compendio medievale, op. cit., pp. 230-231; 304-305.

37 Cfr. S. De Renzi, Storia documentata, op. cit., p. 569.

38 P. Capparoni, Magistri salernitani nondum cogniti, op. cit., p. 21.

39 Cfr. S. De Renzi, Storia documentata, op. cit., p. 569.

40 Costantia was an obstetrician; Mammana was, in fact, a dialectal word used to indicate one. Cfr. P. Capparoni, "Magistri salernitani nondum cogniti. Contributo alla storia ed alla diplomatica della Scuola Medica di Salerno", Terni 1924, p. 23.

41 Cfr. S. De Renzi, Storia documentata, op. cit., p. 569.

42 Cfr. S. De Renzi, Collectio Salernitana, op. cit., I, pp. 372-373.

43 Trotula de Ruggiero. Sulle malattie, op. cit., p. 6.

44 Cfr. Trotula. Un compendio medievale, op. cit., p. 85.
} 
then $^{45}$. The few surviving accounts state that she hailed from the Salernitan nobility ${ }^{46}$. She got her surname from Enrico Baccio: Trotula seu Trottola de Ruggiero, multae doctrina matrona Salernitana, quae librum scripsit de moribus mulierum et eorum cura, et alterum de compositione medicamentarum ${ }^{47}$. Furthermore, de Renzi states that there is a high degree of probability that Trota's teacher was the famous Garioponto, already named hereinabove ${ }^{48}$.

According to de Renzi, Trota married a physician, Giovanni Plateario ${ }^{49}$, with whom she had two children - Giovanni and Matteo - who would dedicate themselves to medicine as well. Both were known in Salerno as magistri Platearii ${ }^{50}$. The younger of the two, Matteo, refers to their mother as magistra in one of his treatises, thus indicating her role in the society of Salerno ${ }^{51}$. It should be added that de Renzi contributes an interesting piece of information, as, in his Collectio Salernitana, when describing the history of the School and its most famous physicians, he names a certain Giovanni Plateario, stating that his mother practised medicine as well ${ }^{52}$.

Trota is known, above all, for her works; it would, however, be a mistake to think of her as merely an author of medical texts. She was actually well-respected as a physician by her peers in Salerno, who would seek her advice. As evidenced by a thirteenth-century work titled De mulierum passionibus, on a certain day, Salerno was visited by a suffering woman, with Trota called upon "as if she were a master of this craft". The physician brought the ill woman to her home, where she diligently examined her and discovered that the cause of her patient's pain was not, as she had previously believed, hernia, but a different disease that she managed to cure with baths and other forms of treatment ${ }^{53}$.

Trota was known not just by the physicians who worked in Salerno at the time, but by authors of medical works who would quote passages from those of her own as well. It is known that Peter of Spain, the future Pope John XXI, quoted Trota's advice in his own work titled Thesaurum Pauperum ${ }^{54}$. She was also proudly quoted by Cofone, a physician, during his journey to France ${ }^{55}$.

It should also be noted that, given the fact that her name was mentioned in non-medical works as well, Trota likely enjoyed significant fame. She is, for example, mentioned in

45 Cfr. Collectio Salernitana, op. cit., p. 152.

46 Cfr. S. De Renzi, Collectio Salernitana, op. cit., I, p. 152.

47 S. De Renzi, Collectio Salernitana, op. cit., I, p. 151.

48 Cfr. S. De Renzi, Storia documentata, op. cit., p. 168.

49 Cfr. De Renzi S., Collectio Salernitana, op. cit., I, p. 152. It should be emphasised, however, that scholars contest whether Trota and Giovanni were really married; in the studies dedicated to her, Monica H. Green hypothesises that Trota could have been the wife of a certain Copho Zoffus. According to Green, the marriage took place in 1112 , but, as emphasised by the author herself, there is no certainty whether this marriage was that of the Salernitan physician; cfr. Trotula. Un compendio medievale, op. cit., p. 90. Further reading: M.H. Green, Reconstructing the 'oeuvre' of Trota of Salerno in: La scuola medica salernitana. Gli autori e i testi, D. Jacquart, A. Paravicini Bagliani (ed.), Tavarnuzze-Impruneta, Florence 2007, pp. 183-233.

50 Cfr. De Renzi S., Collectio Salernitana, op. cit., I, p. 152.

51 Cfr. Trotula de Ruggiero. Sulle malattie, op. cit., p. 6.

52 Cfr. Collectio Salernitana, op. cit., I, p. 152.

53 Cfr. De curis mulierum in Trotula. Un compendio medievale di medicina delle donne, M.H. Green (cur.), Florence 2009, p. 214; De Renzi S., Collectio Salernitana, I, pp. 153-154.

54 Cfr. Ibidem, p. 7.

55 Cfr. Trotula de Ruggiero. Sulle malattie, op. cit., p. 7. 
Geoffrey Chauncer's Canterbury Tales ${ }^{56}$. Furthermore, Orderic Vitalis, already mentioned hereinabove, stated that in 1059 Rudolph Mala Corona arrived in Salerno, famous for its physicians, but failed to find anyone better in the field of medicine "aside from a certain knowledgeable woman" ${ }^{57}$. While the woman's name is obviously amiss, it is likely that the knowledgeable woman in question was Trota. Furthermore, according to the French poet Rutebeuf, she was the most intelligent woman in the world ${ }^{58}$.

With the passing of time, Trota's name began to vanish from history and became the stuff of legend. Historians questioned her very existence; in 1924, Charles and Dorothea Singer maintained that she was a fictional character that never actually lived ${ }^{59}$. Apart from this, some scholars maintain that Trota was a man, as it was difficult to believe that a text as important as De passionibus mulierum could have been written by a woman. Furthermore, in 1566 Hans Kaspar Wolf published De mulierum passionibus, stating it to be authored not by Trota, but by a certain Eros, a slave freed in the 1st century by Empress Julia: Eros quem aliqui Trotulam inepte nominant ${ }^{60}$.

In 1921, Konrad Hiersemann, a student of Sudhoff, mentioned the name of Trottus, the author of various passages of De aegritudinum curatione ${ }^{61}$. In reference to this, it should be added that, in the course of her research, Monica Green reached a conclusion pertaining to the presence of the name "Trottus". According to her, in Southern Italy, there existed no masculine forms of the name "Trota". Trottus did not exist ${ }^{62}$.

It should be added that, in 1837, a work titled De aegritudinum curatione was found in Breslau, written at the end of the 12th century or at the beginning of the 13 th. The text was divided in two parts, with the first describing various types of fevers, and the second indicating treatments for a number of diseases. At the end of the final part, the opinions of seven of Salerno's most famous physicians were found: Giovanni Plateario, Cofone, Petronio, Afflacio, Bartolomeo, Ferrario, and Trota ${ }^{63}$. Unfortunately, however, the text has not survived, and the circumstances of its disappearance remain unknown.

Above all else, Trota is known for her De passionibus mulierum, a work translated into French, German, Irish, Catalan and Italian ${ }^{64}$ and composed of three treatises: Liber de sinthomatibus mulierum, De curis mulierum, and De ornatu mulierum. The first, Liber de sinthomatibus, pertains to obstetrics and gynaecology, with De curis mulierum tackling questions associated with gynaecologic and cosmetic problems, and De ornatu mulierum discussing hygiene and cosmetics.

\footnotetext{
56 Cfr. Geoffrey Chaucer, I racconti di Canterbury, E. Barisone (ed.), Milan 1986, p. 125-126.

57 The ecclesiastical history of Orderic Vitalis, vol. II, ed. M. Chibnal, Oxford 1969, p. 76

58 Cfr. Rutebeuf, Oeuvres complètes, Paris 1839, p. 256: ... ainz suis à une dame qui a non madame Trote de Salerne... et sachiez que c'est la plus sage dame soit enz quatre parties dou monde.

59 Cfr. Trotula de Ruggiero. Sulle malattie, op. cit., p. 8.

60 Trotula. Un compendio medievale, op. cit., p. 4, n. 7.

${ }^{61}$ Cfr. Trotula de Ruggiero. Sulle malattie, op. cit., p. 9.

62 M.H. Green, Reconstructing the Oeuvre of Trota of Salerno in: La Scuola Medica Salernitana. Gli autori e $i$ testi, D. Jacqart and A. Paravicini Bagliani (ed.). Convegno internazionale Università degli Sttudi di Salerno 3-5 novembre 2004, Florence 2007, p. 185.

${ }_{63}$ Cfr. Trotula, il medico, op. cit., p. 101; A.M. Garbarino, Donne e medicina, op. cit., p. 39.

64 Cfr. A.M. Garbarino, Donne e medicina, op. cit., p. 38.
} 
Scholars, however, do question whether Trota was indeed the author of the entirety of $D e$ passionibus mulierum. As a matter of fact, only De curis mulierum has been considered to be connected to Trota since the text was found, with the other two circulating as anonymous works ${ }^{65}$. It would seem well-timed to add that De aegritudinum curatione contained texts by the Salernitan physician pertaining to, for example, epilepsy and dental problems ${ }^{66}$. Her texts were also found in Madrid, in a manuscript titled Pratica secundum Trotam, describing mainly problems of a gynaecologic and obstetric nature ${ }^{67}$.

As stated by Garbarino, Trota authored texts found in De aegritudinum and Practica secundum Trotam, yet is only attributed De passionis mulierum; having written De curis mulierum, the two other texts have been connected with her name as well ${ }^{68}$.

The problem surrounding the author of these texts is a very complex one. One could cite the opinions of various scholars - however, this is not the focus of the present study ${ }^{69}$.

\section{Trota's bodily treatments}

In her treatises, Trota presented not just health treatments, but ones associated with bodily beauty as well. In De curis mulierum and De ornatu mulierum, the author provides instructions on how to treat one's hair, skin and teeth, emphasising the importance of proper nutrition and everyday hygiene. According to her, even unattractive women could improve their looks if they took good care of their skin. Reading her texts, one may immediately note how frequently Trota mentions the importance of baths during which women would wash their hair using gallic soap, or spread various creams on their bodies. Even at the very beginning of De ornatu mulierum, the author states that: "In order to render the female body smooth, soft, and free of hairs from head to toe, the woman needs to, above all, go to the baths" Furthermore, Trota's texts are a source of knowledge pertaining to the use of gallic soap ${ }^{71}$ and various filtered waters that were meant to soften the body during bathing. The author provides instructions on preparing "shampoo", depilation creams, perfumes, and "toothpastes".

Trota provided advice on the means to render one's skin delicate, soft and shiny. The multitude of suggestions that her works provided regarding caring for one's hair, face and teeth are a testament to the fact that such concerns were considered natural and normal. Furthermore, as stated hereinabove, Trota's texts frequently emphasised the importance of bathing, which allows us to belie the myth that the people of the Middle Ages did not believe hygiene to be a matter of high priority.

${ }_{65}$ Cfr. Trotula. Un compendio medievale, op. cit., p. 3.

${ }_{66}$ Cfr. A.M. Garbarino, Donne e medicina, op. cit., p. 39.

${ }^{67}$ Cfr. Ibidem, p. 39.

68 Cfr. Ibidem, pp. 39-40.

${ }_{69}$ Further reading: Trotula. Un compendio medievale della medicina delle donne, M.H. Green (ed.), Florence 2009.

70 De ornatu mulierum in: Trotula. Un compendio medievale di medicina delle donne, M.H. Green (cur.), Firenze 2009, p. 276-277.

71 Ibidem, p. 292-293. 


\subsection{Body treatments}

In De ornatu mulierum, Trota provides instructions on the preparation of rosewater, used to give the body a pleasant smell. The physician advised making a powder consisting of dried roses, cloves, nutmeg, watercress and blue ginger. Afterwards, she wrote, one needed to "mix all of these ingredients, once reduced to powder, with rosewater" 72 . For foul-smelling sweat, she recommended drenching the internal parts of clothes with wine that had been used to boil blueberries ${ }^{73}$.

Furthermore, Trota describes vapour baths, following which women were to perform depilation of their bodies. The recipe for a depilatory cream composed of well-dried quicklime gave the following directions: "place three in a potter-made container, then boil them as if they were polenta. Afterwards, take an ounce of orpiment, then cook once again" 74 . Trota warned against cooking the ingredients too much and leaving them on for too long, as "this generates immense heat" 75 . According to another recipe, the ingredients were to be placed in a small linen sac, then boiled until cooked. The author suggested adding a small amount of water should the cream become too thick ${ }^{76}$. Once the cream was spread on the body, the woman was to enter a vapour bath, then, after the passing of a few minutes, begin depilation. Having performed these steps, she would then bathe in warm water, ensuring to wash herself thoroughly ${ }^{77}$. Trota also recommended bringing a filter composed of bran mixed with hot water, then washing one's body with the liquid following depilation in order to purify the skin and make it smooth ${ }^{78}$. In order to remove unwanted hairs definitively, Trota recommended that one: "take ant eggs, red orpiment, and ivy gum, then mix them with vinegar and rub the mix where desirable" "79. The variety of the recipes meant for the removal of undesired bodily hairs shows that their presence was deemed unhygienic even back in the times of Trota.

\subsection{Hair treatments}

Once the bath was finished, the next step was to take care of one's hair. Before everything else, it was to be washed using a detergent prepared in the following manner: "take some vine cinder, a husk of barley, liquorice wood and sowbread; boil the barley and bread in water. Fill a vase with two or three small perforations at the bottom with the barley, cinder and sowbread. Pour the water previously used to boil the barley and sowbread into the container so as to filter it using the small perforations" $"$. The woman was to wash her hair using that ingredient in order to have "shiny" and "golden" hair. ${ }^{81}$ It is, however, the next stage, not employed commonly today, that piques particular interest. Trota recommended

\footnotetext{
72 De ornatu mulierum, op. cit., pp. 282-283.

73 Cfr. De curis mulierum, in: Trotula. Un compendio medievale di medicina delle donne, M.H. Green (cur.), Firenze 2009, p. 252-253.

74 De ornatu mulierum, op. cit., p. 276-279.

75 Ibidem, pp. 278-279.

76 Ibidem, pp. 278-279.

77 Ibidem, pp. 280-281.

78 Ibidem, pp. 280-281.

79 Ibidem, pp. 290-291.

80 Ibidem, pp. 282-283.

81 Ibidem, pp. 282-283.
} 
preparing powder made of dried roses, cloves, nutmeg, watercress, and blue ginger. Once the ingredients were powdered, they were to be mixed with rosewater ${ }^{82}$. The final product was to be sprayed not just on one's hair, but on combs as well, in order to improve the hair's fragrance. To noblewomen, Trota recommended carrying nutmeg or cloves in one's hair ${ }^{83}$.

De ornatu mulierum contains instructions on treatments aiming to make one's hair soft, shiny, and delicate. According to Trota's recipes, one should wash their hair using hot water with added natron and vetch powder ${ }^{84}$. The text also features advice on methods of rendering one's hair black or golden. According to this, when a woman wished to give her hair a golden colour, she would have to cook the viscous liquid remaining at the bottom of the barrels used to make white wine (fondi di vino) with honey, then grease the hair using the resulting product ${ }^{85}$. In turn, when a woman wished to blacken her hair, the text suggested boiling myrtle flowers with salvia sclarea in vinegar, then applying the resulting mix on $\mathrm{it}^{86}$.

Describing hair loss, Trota wrote: "catch as many bees as you can in a new ceramic jar, place it on a fire, mince them in oil, then apply the resulting blend on your head ${ }^{87}$. When it came to regrowing one's hair, one had to burn barley bread, then mix it, the crust included, with salt and bear fat. The product thus obtained was to be spread on the parts of the body where one desired to regrow their hair ${ }^{88}$.

\subsection{Face treatments}

When discussing visage, Trota states that "when one's face is adorned splendidly, even unattractive women may become beautiful" "99. The Salernitan advises women to wash their faces with warm water and gallic soap, using a bran filter as well. Furthermore, after the washing, the woman was to grease her face with oil of $\operatorname{Tartar}^{90}$. According to Trota, no facial hair was to be present. In order to remove it, she recommended the following treatment: "Take rosin and wax, then melt them in a clay vase. Having done this, add a small drop of galbanum, then cook the mixture for a long time stirring it using a spatula. In the same manner, take mastic, incense and gum arabic, then add them to the rest" ${ }^{\prime 91}$. Having created this mixture, the woman was to apply it while it was tepid, keep it on for about an hour, then tear it away. This procedure would not merely remove the undesired facial hair; it would also lighten the skin, giving it an aesthetically-pleasant tone. When it came to methods of whitening the face, Trota authored many recipes. One of them said, for example: "(...) boil deer tallow in water. Afterwards, filter it with water stored in another vessel, and, once done, stir it for a long time using your hands, then add some crystal powder and varnish" ${ }^{\prime 2}$. According to another recipe,

\footnotetext{
82 Ibidem, pp. 282-283.

83 Cfr. Ibidem, pp. 282-283.

${ }^{84}$ Cfr. Ibidem, pp. 286-287.

85 Cfr. Ibidem, pp. 286-287.

${ }_{86}$ Cfr. Ibidem, pp. 288-289.

87 Ibidem, pp. 288-289.

88 Cfr. Ibidem, pp. 288-289.

89 Ibidem, pp. 292-293.

90 Cfr. Ibidem, pp. 292-293.

91 Ibidem, pp. 294-297.

92 Ibidem, pp. 300-301.
} 
one needed to crush a lily root until it becomes white. Afterwards, one was to head to the baths, add one or two eggs to the crushed root, wait for some time, then apply the product on her face. The mixture was to be removed when the woman wanted to leave the baths ${ }^{93}$.

\subsection{Treatments for the lips}

When taking care of their faces, Trota maintained, women could not forget about taking care of their lips. The best product to this end was honey foam with the addition of "a little white bryony, red bryony, touch-me-not, and a little rose water" 94 . The ingredients were to be boiled and later spread on the lips. According to another piece of advice provided by Trota, if a woman's lips were chapped, she needed to rub them with rose or flax oil cooked with sowbread ${ }^{95}$, but, as stated by the physician, wormwood was perfect for alleviating this problem as well ${ }^{96}$. De curis mulierum contained other remedies for lip cracking caused by physical contact with lovers or exposure to the air and wind as well. Among the advice provided, Trota suggested rubbing one's lips with honey and spreading rosin on them ${ }^{97}$.

An interesting note that should be added is that the Salernitan physician also described ways to colour one's lips. In fact, De ornatu mulierum contains a recipe for preparing cosmetics used to this end. The first step was to prepare one's lips; they were to be rubbed with the bark of a walnut tree root $^{98}$. Afterwards, the colouring was to be prepared as follows: "Take the kind of seaweed that the Saracens use to paint their skin green. Leave it to boil in a new clay vase with and egg white until the volume is reduced by a third. Add finely-minced red wood to the filtered substance, then let it all boil once again... once the mixture is tepid, add alum powder, then pour it into a golden or glass ampule" 99 .

\subsection{Treatments for the teeth}

Another problem addressed by Trota was unpleasant breath. According to her, one was to prepare aloe powder, then mix it with wormwood juice. One was to take four spoonfuls of the obtained syrup every morning, followed by four spoonfuls of honey ${ }^{100}$.

When it came to taking care of one's teeth, the Salernitan physician authored several pieces of advice. According to one of these, one was to "wash her mouth after dinner with high-quality wine, then afterwards dry her teeth using a new, white cloth"101. Another method entailed combining cinnamon, cloves, spike lavender, mastic, incense, grain, wormwood, a crab pincer, date seeds and olives, then reducing the ingredients to powder ${ }^{102}$. For black teeth, Trota recommended to: "take nutshells, thoroughly cleaned of the green internal bark,

\footnotetext{
Cfr. Ibidem, pp. 300-301.

Ibidem, pp. 306-307.

Cfr. Ibidem, pp. 308-309.

Cfr. Ibidem, pp. 308-309.

7 Cfr. De curis mulierum, op. cit., pp. 242-243.

98 De ornatu mulierum, op. cit., pp. 308-309.

99 Ibidem, pp. 308-309.

100 Ibidem, pp. 310-311.

101 Ibidem, pp. 312-312.

102 Cfr. De curis mulierum, op. cit., pp. 272-273.
} 
then rub them on your teeth thrice daily; once the procedure is done, wash your mouth with hot wine"103.

\section{Conclusion}

Trota's treatments described in this study show that, even back in her times, women wished to remain beautiful and attractive for as long as possible. Seeing the contents of De ornatu mulierum and De curis mulierum, one can clearly see that they were more than but advice for women who wished to keep their skin soft and smooth, their hair fragrant and beautifullytinged, their lips smooth, and their teeth white. In fact, the variety of the treatments described allowed women to choose the recipes they found to work best for them.

The present study, based on texts authored by Trota, shows that having smooth skin is not a fleeting trend followed by modern women - on the contrary, women sought to keep their skin hairless even back in the 11th century. Moreover, Trota's treatments show that soap, shampoo, toothpaste, and depilatory creams existed even in those times, reputed by many to be the dark ages of hygiene, when filth reigned supreme.

\section{The remedies to refine the beauty of the body according to the teaching of Trotula of Salerno Summary}

Trotula of Salerno lived in eleventh century Italy and was one of the few women who received an excellent education. Trotula was an unusual woman who, thanks to her talents, became famous not only in Salerno, but also in the whole of Italy and outside of the country. Her name can be found in various medieval writings, as for example in the Canterbury Tales written by Geoffrey Chaucer. She was not only a doctor, but also the author of medical treatises. One of her works, entitled De ornatu mulierum, shows what kind of "cosmetics" the women of medieval Salerno used. Thanks of her writings, it is known how the women of the time took care of their bodies. She taught how to remove unwilling hair, and that it was necessary to have white, healthy teeth, smooth skin, and long black or blonde hair.

Keywords: Trotula of Salerno, beauty, De ornatu mulierum, Italy, Middle Ages

About the author: Anna Glusiuk $\mathrm{PhD}$ is an assistant professor at the Institute of Historical and Social Sciences at the Cardinal Stefan Wyszyński University. Scientific interests: Medieval Literature, the situation and the role of women in the Middle Ages.

${ }^{103}$ Ibidem, pp. 240-241. 